\title{
Mis-Educative Martial Law - \\ The Fate of Free Discourse and the Moral Judgment Competence of Polish University Students from 1977 to $1983^{1}$
}

\author{
Ewa Nowak \\ ORCID: https://orcid.org/0000-0002-5722-7711 \\ (Adam Mickiewicz University in Poznań, ewanowak@amu.edu.pl)
}

\section{Georg Lind}

(University of Konstanz, georg.lind@uni-konstanz.de)

\section{Foreword}

Poland is still a young democracy. The transition from an authoritarian to a democratic society happened only twenty years ago. It was not an easy transition, as the first author witnessed as a school student and later as a university student. The second author witnessed this transition in Poland from outside the "Iron Curtain", as the border in Europe between the Western capitalistic, democratically ruled countries and the Eastern communist, autocratically ruled countries was called. He participated in an unusual longitudinal study of university students in Western and Eastern European countries. A research grant of the Humboldt Foundation to the first author made it possible to combine both viewpoints and discuss the democratic transition of Poland from two very different angles, not only from two different national backgrounds but also from two different professional points of view, namely moral philosophy and experimental psychology. The question from which we departed was of a general kind: How can the gap between democracy as an ideal and as a way real life be bridged? The answer to this question, it seems, cannot leave out the role of law and education.

1 A reprinted and slightly updated paper originally appeared as E. Nowak \& G. Lind (2009), "Miseducative Martial Law: The Fate of Free Discourse and the Moral Judgment Competence of Polish University Students from 1977 to 1983". In B. Wojciechowski, M. Zirk-Sadowski, \& M. J. Golecki (Eds.), Between Complexity of Law and Lack of Order, Adam Marszałek Editions, Torun/Bejing (pp. 145-165, in English and Chinese). Paper presented at the Annual Congress of American Association of Moral Education, New York University Nov 2007. Ewa Nowak's thanks are going to the Alexander von Humboldt-Foundation which supported her research at the University of Konstanz (2008-10). 


\section{How Can We Bridge the Gap between Democracy as an Ideal and as a Way of Life?}

The general view is as follows: Law derives its legitimacy through its moral basis and the process by which it comes into being. In a democracy the law is made by the people or its elected representatives. More specifically, it is legitimated by the shared moral principles on which people agree like justice, respect for human rights and lawmaking according to procedures of "presumptively rational opinion- and will-formation" (Habermas 1996, 457). "Valid legal norms," Habermas points out, "indeed harmonize with moral norms, but they are 'legitimate' in the sense that they additionally express an authentic self-understanding of the legal community" (cf., 157). Ultimately, as Gustav Radbruch, an eminent law-professor and former secretary of law, has observed, democratic law rests on the intuition of rightness ("Rechtsgefühl").

In contrast, in an autocratic society, law is legitimated by the power of the lawmakers alone. This gives law a weak basis because the people do not take interest in maintaining the laws nor do shared moral principles support them. Their enforcement depends solely on the judgment of the people in power. On the one hand this makes it easy for them to utilize the law as a power-maintaining tool. On the other hand, those ones in power also have to resolve all disputed matters, they must find solutions for conflict between various laws and bear all the consequence of the mal-functioning of society. A non-democratic, authoritarian law can only work if those in charge are infinitely wise und competent rulers, which is a very unlikely scenario. An authoritarian ruler can coerce people by force to abide by authoritarian law, but this law will always lack moral legitimacy and rightness. For this reason, the law system in a democratic society has a great advantage over the law system in an autocratic state.

However, this view needs to be supplemented. Peoples' intuition of rightness is not a sufficient basis for the functioning of a democratic society. Universal moral principles and specific rights and liberties are too complex to lend themselves to easy interpretation and application by the citizens of a democratic state. The citizens need to develop high moral judgment and discourse competence (Gutmann 1999; Habermas 1995; Kohlberg 1970; 1975; Lind 1987, 2008a). Moral judgment competence, as Kohlberg (1964) has defined it, is "the capacity to make decisions and judgments which are moral (i.e., based on internal principles) and to act in accordance with such judgments" (cf., 425). Moral judgment competence means more than a trait of individual thinking as it also involves moral discourse competence. Therefore, in research studies, participants are not only asked to provide reasons for their decision on a particular moral dilemma, but are confronted with counter-arguments in order to test their ability to apply their moral ideals to controversial matters in a discourse situation (Lind 1978; 2016). ${ }^{2}$

2 Unfortunately, in Kohlberg's interview method the discourse component has been dropped in the course of later revisions (cf. Lind 1989). In contrast, Lind has made this component a central feature of his test (see below). 
If the learning environment in a society is favorable, judgment and discourse competence can develop in their own right, at least to some extent. Yet, in the face of growing moral challenges in all domains of modern life, "natural" development of moral and democratic competencies may not be enough and must be fostered by appropriate education (Schillinger 2006; Lind 2002).

Finally, democratic education is a "bootstrapping process": On the one hand, schools in a democracy must foster moral-democratic competencies in order to narrow the ever existing gap between the moral ideal of democracy and the really existing democratic way of life. At the same time, a democratic system is a precondition for more democratic discourse at schools. Obviously, this bootstrapping process hardly ever comes to an end. The world around us is changing fast and poses ever new challenges for individual moral judgment as well as for the democratic decision-making process. It even seems that this process is also never linear, stepby-step, as $19^{\text {th }}$ century philosophers like Hegel and Marx assumed, but is characterized by changing phases of progress and backlash.

In this paper we want to analyze this fuzzy development of the democratic state in the case of Poland, a country which is considered to be one of the first communist countries in which democratization took place. We argue that the political processes of democratization and its reversal by the military rulers not only impacted the law and other social institutions but a (mis-) educative effect on the citizens. Clearly, political movements are not meant to educate or mis-educate citizens. Rather, schools are the proper agent for moral and democratic education (Radbruch 1993; Dewey 1966; Gutmann 1999; Kohlberg 1980; Lind 1987; 2016). Yet the state and its laws can also be a powerful (mis-)educative agent by providing, or withdrawing, opportunities of responsibility-taking and free discourse. We will present empirical evidence for the fact that military dictatorship during the time of martial law in Poland contributed not only to the strangling of the process of democratization, but also to the changing of democratic moral judgment competence among students. Under martial law, laws were decrees introduced by the military rulers lacking any grounding in generally shared moral principles and democratic procedures. Basic civil rights and elementary liberties were discarded or flatly disregarded. Especially the right to speak freely and participate in a free moral discourse was discarded. During the whole period of communist rule in Poland after World War II, citizens suffered under unjust laws, but never to the extent experienced after the imposition of martial law in 1981.

Our analysis has been facilitated by the availability of longitudinal data on the development of moral judgment competence of university students in Poland during the very turbulent phase of the democratization process and its reversal by military forces within the government before December, 1981, when General Jaruzelski seized power and established martial law in Poland. We will discuss the empirical findings in the light of three competing theories, a) education theory of moral development, b) socialization theory, and c) decision-making theory. Finally, we present some observations of moral judgment competencies in contemporary Poland. 


\section{The Longitudinal Study of Moral Judgment Competencies of Polish Students (1977 to 1983) by the FORM-Project}

The international FORM-Project, funded by the Deutsche Forschungsgemeinschaft, conducted a longitudinal, cross-national study of about 4000 university students in five European countries, Austria, Germany, the Netherlands, Slovenia (at that time still part of former Yugoslavia), and Poland. Poland participated three times in these assessments (1977-1983), the other countries four times (1977-1985). This project was co-directed by Prof. H. Peisert, Konstanz, and Prof. W. Markiewicz, Poznań/Cracow (cf. Bargel, Markiewicz, \& Peisert 1982).

As part of this study, students' moral development in these countries was assessed. For this assessment, Georg Lind had developed a new instrument for measuring moral competence, namely the Moral Competence Test (MCT; cf. Lind 1978; 2016). ${ }^{3}$ The master copy was written and validated in German, and then translated into Polish, Slovenian and Dutch. In meantime, the MCT has been translated and validated in about 30 languages and is in use in educational research and evaluation projects in countries such as China, Colombia, Italy, Mexico, Morocco, Russia, the USA, and many more (Lind 2016).

The MCT is based on Lind' dual-aspect theory of moral behavior (Lind 2002; 2016). The theory asserts that when studying moral behavior one must distinguish two essential aspects, moral ideals or principles on the one hand, and moral abilities or competencies on the other. For centuries, morality has been seen purely as a matter of moral affects, i.e., as a matter of valuing or loving moral principles. A behavior was said to be morally good, if it was based on good intentions but nothing else. Many have pointed out the shortcomings of the omission of the consequences of one's action from the definition of what is morally good or bad. Yet considering the consequences of one's action is only one of the difficulties which we encounter when we pursue moral principles in every-day life. A second important aspect concerns the problem of conflicting moral principles. We often run into situations where more than one moral principle is involved and no single course of action is morally right. How can we resolve such a moral dilemma?

Obviously, moral ideals are not enough. We also need an ability to translate our moral ideals into every-day decision-making or, what Kohlberg (1964) called, moral judgment competence. The dual aspect theory implies that moral ideals and moral competencies are two distinct but not separable attributes of the same moral judgment behavior (Lind 2016; see also Piaget 1976) and also that the two must be measured simultaneously and not as separate components through different tests. In fact, the MCT permits us to measure the two main aspects of moral judgment behavior simultaneously. It enables us to measure (a) six moral orientations as distinguished by Kohlberg (1984), which we consider the affective aspect of moral behavior, and (b) the ability to apply these orientations to a particular decision-making situation (its cognitive aspect). 
The six moral orientations are measured in a classical attitude-test manner by summing up all ratings that represent that orientation. In contrast, the ability-aspect is measured by employing concepts from experimental psychology. In fact, the MCT is designed as a multivariate experiment and not like a classical psychometric test (Lind 2016). After reading two moral dilemmas, the participant first has to state his or her opinion about the protagonists' solution. Second, the participant has to rate six arguments supporting his or her opinion and six arguments opposing it. The respondent rates each argument on a nine-point scale from -4 ("strongly reject") to +4 ("strongly accept"). On each side, each argument represents one of the six Kohlbergian moral orientations. ${ }^{4}$ The standard version of the MCT consists altogether of 24 arguments, each representing a certain decisional context (dilemma), a certain opinion on the decision made in that context, and one of six moral orientations. Thus the MCT forms an $2 \times 2$ x 6 experimental design.

Because of this experimental design, the MCT allows us to determine which of the three different factors built into the test (decision context, opinion dis-/agreement, and moral quality of the argument) determines a participant's pattern of responses. From experimental studies we know that most people have a strong inclination to rate arguments on the basis of their "opinion-agreement" rather than their moral quality (Keasey 1974). That is, most people feel compelled to adhere to their opinion on a certain issues rather than critically discuss their opinion in the light of their own moral principles, which is a prerequisite of a moral discourse. Hence, the core task for the participant is to rate the arguments given in the test in regard to their moral quality rather than their opinion-agreement. To construct a quantitative score of moral judgment competence, the total response pattern of each respondent is analyzed using an intra-individual multi-variate analysis of variance. The resulting $\mathrm{C}$-score ("C" for competence) is the proportion of the variance of the acceptance-rating accounting for the moral quality of the arguments. A detailed description of the MCT and its rationale can be found in Lind (2016).

For a number of reasons, in the Polish study only one dilemma, the so-called doctordilemma, was used. Hence, the C-score of the Polish students cannot be directly compared to those in other studies. To be able to make comparison possible, we also re-analyzed the data of the German university students who participated in the FORM separately for the doctor dilemma. Note also, that in the Polish sample the response scale was shortened to a seven-point scale (from -3 to +3 ). But this has no impact on the C-score.

The findings in regard to the affective aspect show, that, regardless of the ideological system, Polish students had essentially the same moral orientations as the students in the West European countries (Lind 1986). They preferred universalizable, principled moral orientations over positive law orientation, peer-group norms, and materialistic orientations, and these moral orientations do not change, indicating that these moral ideals are common and highly stable.

In contrast, during the period from 1977 to 1982, the moral judgment competence of

4 Note that we do not speak of moral "stages" because our theory of moral development does not imply the existence of stages as Kohlberg (1969) has defined them. We use Kohlberg's scheme merely to categorize moral arguments, not people. 
Polish university students showed an unusual development. The average scores first rose and then sunk (see Figure 1). At the same time, university students in Germany showed a smaller yet continuous increase of C-scores over the full range of the study on them. Note also that the initial level of moral judgment competence of the Polish students was much lower than that of the German students, indicating that German students experienced a more favorable learning environment in the 1970's than the Polish students.

Why did the moral development of many Polish university students first increase so impressively (more than that of German university students at the same time) and then show such a dramatic decrease (which was not the case with the German students)?

We believe that this phenomenon can best be explained by the process of democratization which occurred during that time and its reversal by the coup d'état of the military. During the first period of this study, between 1977 and 1979, students experienced the atmosphere of semi-legal discursive freedom, tolerated by some university teachers. They participated in the (illegal) critique of the legal order of that time and hopefully expected to change it. They witnessed spectacular events which raised the moral prestige of Poland in the eyes of the whole world: the election of a Polish cardinal as pope in 1979, the legalization of the labor union "Solidarity" in 1980, and the Nobel-Prize for the poet Czesław Miłosz in 1980. They read prohibited literature like Hannah Arendt's The Origins of Totalitarianism, and engaged themselves in the anticommunist movement.

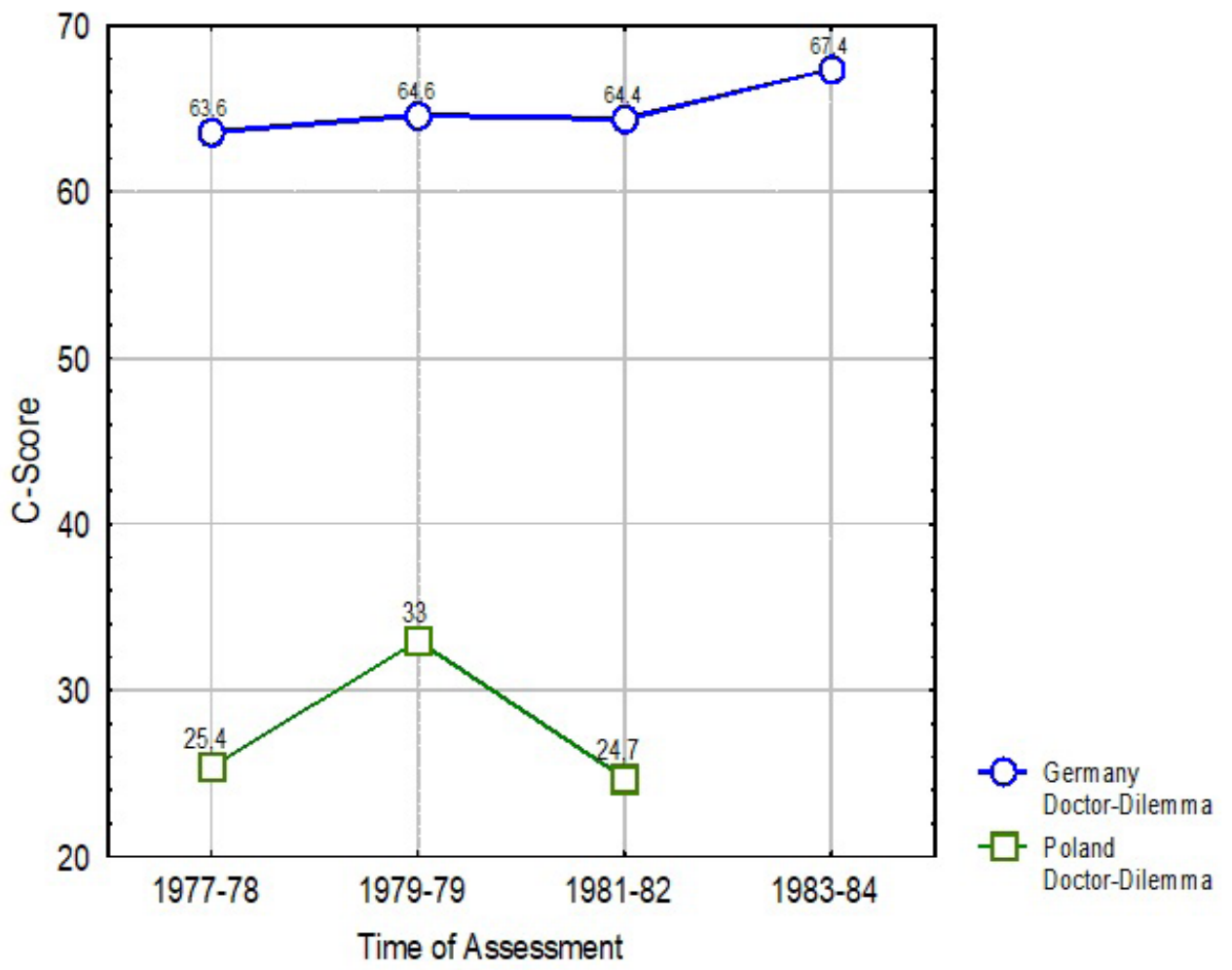

Figure 1. The change of moral competence of Polish and German university students 1977 to 1984, using part of the Moral Judgment Test (only the doctor dilemma) in a longitudinal assessment (only core sample). Polish students ( $N=489)$ were assessed three times, German students (N=700) four times. Data source: FORM project. 
coup d'état (which took place in December, 1981) the young democratic movement was smothered. The military dictatorship, it seems, not only ended the democratization process among institutions in Poland but also had a strong psychological impact. The people involved in this democratization process (of whom many were university students) seemed to have become aware of a chasm between the martial law of the government and the proclaimed moral and social ideals of a communist society (which were not so different after all from the moral ideals of the Western countries). But real life in communist Poland contrasted sharply with these ideals. This chasm created more and more dissatisfaction among the Polish people and finally led to the democratization process. People started to discuss the gap between the declared moral ideals of a communist society and the actual oppression they experienced in everyday-life. They discussed the injustice of the existing laws and the inability of the Polish government at that time to solve the growing social and economic problems. And by doing so they improved their ability to make judgments and engage in a moral discourse.

The reverse process, which happened sometime between 1979 and 1981, is not as easily explained. On the one hand, the moral ideals of the MCT-respondents remained largely intact during this period. There was no change, even less a reversal, of moral orientations. There was no regression of moral ideals, that is, no loss of postconventional moral principles or a preference for conventional and preconventional ones. What deteriorated was students' moral judgment and discourse competence (for a discussion of the phenomenon of "moral regression," cf. Lind 1985; 2000a). The withdrawal of opportunities for responsibility-taking and moral discourse by the authorities, it seems, was dysfunctional for the development and maintenance of peoples' moral judgment competence. To better understand what happened in those times we consider three theoretical accounts of the processes that took place then: the education theory of moral development, socialization theory, and decision-making theory.

\section{Theoretical Accounts}

\section{The Education Theory}

The education theory of moral development (Lind 2002; 2016) implies different courses of development for moral ideals and moral competencies. It implies that moral and democratic ideals are inborn or adopted by children in a very early phase of life. Each person has moral ideals and at least an intuition of what is "right" and "wrong."

However, the theory also implies that moral judgment competence and democratic discourse competence are not inborn but need to be developed by everyone throughout his or her life-span, and that this development requires, in our complex world, the assistance of education. According to education theory, the development of moral judgment competence depends mostly, if not solely, on education, more specifically, on good 
education. This theory is supported by many empirical observations and experimental studies. As cases of real regression of moral development have been observed, we can no longer assume that moral development forms an invariant sequence or that it always correlates with chronological age (Lind 1985; 2002). In the past decade the features of the learning environment could be identified which seem to be particularly important for this development, namely opportunities for responsibility-taking and for guided reflection (Sprinthall et al. 1993; Lind 2000b). Hence, educational theory of moral cognitive development permits us to assume that the development takes place only in a learning environment which leaves room for opportunities for responsibility-taking and free moral discourse. If students do not have access to such an environment, they will eventually lose their moral judgment competence (Lind 2000b; Schillinger 2006; Hemmerling 2014). Only if society and its educational institutions offer opportunities for discourse space can students practice their competencies and eventually reach a level of sustainable moral development (Lind 2000b).

The dual-aspect theory permits us to discern a different impact of the political process on moral orientations and moral competencies: While the introduction of martial law did not affect the moral orientations of the Polish university students, it led to a regression of moral judgment competence because they were deprived of opportunities to practice it. In the atmosphere of hopelessness, fear and terror their judgment competence was disturbed. As Kant would say, we can become "virtuous" only through practicing "virtuous behavior". It is only then, Aristotle would add, that "we feel the virtues at the right times, with reference to the right objects, towards a right people, with the right motive" (Aristotle 2009, 47).

\section{Socialization Theory}

Socialization means acquiring behavior patterns, convictions and attitudes toward moral rules, from outside, from the environment and figures of authority (Mischel \& Mischel 1996). The process of socialization involves conformity and adjustment and not the development of autonomous moral orientations regardless of social pressure. But neither pressure and rigor nor imitation and norm imprinting can foster a personal moral motivation, a competence for moral judgment and the resolution of social conflicts. The growth of logical competencies and learning or even academic ethics are not of much help here. Especially in authoritarian education the socialization methods break down. Certain rules are "adopted" to gain the educator's approval, i.e. for conformist or instrumental ends. Outside the relationships founded on the dependence on authority moral judgment behavior diverges from the educational directives. Hierarchic institutions such as schools, the army, prison, reformatory and rehabilitation institutions are often satisfied with preconventional and conventional orientations in students or inmates, because they 
submit to the institutional rules. This is why people with high moral competence may not always be welcome in social institutions.

Most children already manifest a "sense of rightness" (Radbruch) already at an early age. Moral sensibility precedes the development of discursive skills. Habermas (1986, 269-270) points here to communicative and moral interests, characteristic of a democratic personality. Such interests are developed through democratic behavior. They allow a person a better understanding of social environment when he or she participates in a moral discourse, when his or her own and other peoples' opinions awaken reciprocal respect. The growth of moral judgment competencies observed in Polish students in the years before martial law was introduced occurred in the discursive atmosphere of academic education at universities working under an undemocratic regime. This means that students were interested in mutual communication and recognition, as - undaunted by the lack of any democratic institutions in a public sphere - they had produced their own free discourse space, and discovered and shared social problems on their own. The exchange of moral opinions was constructive for them and they behaved democratically even though the conditions were non-democratic. They criticized official social rules and felt able to change these rules, too. Through free discourse activity and learning from each other the truth about their society they revealed the "critical interest" crucial for a democratic personality. Discursive socialization, in this case, depended on fostering democratic competencies by doing democracy on an interpersonal level. It took place in a student milieu, in a self-made democratic enclave created against the undemocratic conditions existing in communist Poland. So education theory partially overlaps with socialization theory.

Yet, if morality were only the result of adopting an attitude toward external rules, the atmosphere of pressure in which Polish students lived after December 1981 ought to have negatively influenced their moral behavior and orientations too. But instead in the academic circles a solidary, ostentatiously silent resistance to "unjust law" grew.

\section{Decision Making Theory}

Decision making theory (Lewin \& Lippitt 1938; Brehm \& Cohen 1962; Harvey at al. 1974; Seligman 1975) assumes that actual limitation of freedom in the social and political environment disturbs the decision-making process. The more people treasure freedom, and the more it means to them in a political and practical sense, the greater their idecision, resignation, aversion and inconsistency can be when their freedom is drastically limited. This assumption seems to be supported by the fact that respondents lost some of the moral judgment competence that they had acquired when martial law was introduced. Many respondents did not return the test at all or returned an empty form.

The so-called revised decision theory (Adam 1993; Wortman \& Brehm 1996; Herkner 
2004) assumes that people make moral decisions not only on the rational level, but also on an "emotional level" (Herkner 2004, 91). For Dieter Birnbacher (2003), conscious moral emotions are associated with reflection (e.g. compassion, empathy). Reflections express moral acceptance and rejection, as well as a "tangible" moral attitude toward an object of judgment. Only thanks to moral emotions can we "construct" the relevance of moral phenomena.

According to this theory, moral decisions are determined by the "right" or "wrong" aspects of a problem. So a person (1) with a stable level of cognition (a set number of alternative decisions, criteria etc. of which the person is conscious, (2) with a coherent, inert hierarchy of moral preferences, and (3) with a relatively stable tendency toward moral behavior, can make different decisions on the same moral problem if his or her perception of the problem changes. In such a case, judgment is based on the same moral criteria, but the strength of acceptance for the criteria has changed. In other words, the inconsistency of moral decision results depends, as Adam (1993) asserts, on mental, dynamic representation of the social situation: on other persons and relationships with them, personal share in the social problems, and the legal and political situation. Such representation includes cognitive and also affective elements (judgments, doubts as to their adequacy, experiences etc.). From the point of view of the so-called situationawareness theory (ibid.) we could explain the difficult moral judgments situation of the Polish students in this way: If a person feels that he/she does not have a control over his/her life situation or cannot change it, his/her decisions will be influenced by stress and many kinds of its side effects like: aversion, indecisiveness, "learned helplessness" (Seligman 1975) or "cognitive dissonance" (Brehm 1972). A permanent no-choice situation also disturbs moral judgment behavior.

When martial law was introduced, people experienced politically caused stress, repression, insecurity and helplessness. The situation was likely to discourage people from using their moral competence. They felt that 'no choice is the right one', and that each decision would be regretted later (cf. Herkner 2003, 91). In this context, the excerpt from General Jaruzelski's speech of $13^{\text {th }}$ December 1981 sounds especially ominous: "The nation has reached the limits of its psychological endurance."

In sum, the military coup d'état in Poland had limited the opportunities for moral learning. Yet even before this moral judgment competencies had not been an educative goal of the Polish schools and universities. This topic was taboo as in most autocratic countries. The chasm between the political order, the authoritarian form of power execution and law making had always been mis-educative, as the overall low level of moral judgment competence of Polish university students during that time shows. The short period of democratization with its educational impact on the university students and the subsequent reversal of moral development when the democratization process was ended with brute force demonstrates the (mis-)educative impact that the state can have.

But this direct impact of the state on moral development is limited. In 1989 
Polish society had obtained democratic liberties and a democratic constitution but the development of moral and democratic competencies was still an ongoing process. A rather small group of democratic activists had helped to overcome the communist dictatorship through strikes and demonstrations. These activists had an opportunity to learn democratic discourse behavior and developed moral judgment competencies through reflections and discussions, and by taking responsibility for the fate of their country. However, the vast majority of citizens still hardly participated in this democratic opinionand will-formation process. They certainly shared the democratic ideal of liberty and the rule of just laws, but they still seemed to lag behind in the ability to apply the democratic ideal in every-day life. This becomes apparent in the slighting of the legitimacy of legal rules and in the questioning of the validity of court judgments; in viewing the law through the lens of the subjective "intuition of rightness" and "my right"; and in the inability to justify the law with the help of universal moral criteria, such as fairness, justice, basic civil liberties, human dignity, and respect for each human being.

The young people born after the democratic revolution in Poland have not directly experienced the mis-educative influence of martial law and dictatorship. Yet, it seems, they also still live in a time of transition between dictatorship and democracy. Even today, many Polish high schools, and the university students, manifest indecisiveness in the public space. Their mistrust sharply contrasts with the willingness of students in West-European or Latin American countries to take a stance in a dilemma discussion. For example, a class of Polish high school students refused to vote when they were asked whether they thought the decision of a fictitious person presented in a dilemma discussion was right or wrong. It did not help that the teacher re-assured them of a free discourse and that they were not graded for their answers. However, the factual experience of free discourse in the discussion afterwards, which was conducted according to Lind's KMDD method (Lind 2008b; 2016), seems to have effectively produced trust. At the end, only ten percent of the students refused to vote when they were asked a second time for their opinion on the decision. This observation implies that Polish students are in need of a good democratic education that strengthens their "sense of rightness." Yet it also shows us that such an education would be possible and successful.

\section{Strengthening Moral-Democratic Competencies through Effective Moral- Democratic Education}

As research studies and intervention studies indicate, education is most effective in promoting moral and democratic competencies if characterized by three essential features (Lind 2002b; 2016; Nowak et al. 2013):

1. A communication climate of free discourse and mutual respect. What happens in argumentation in a free discourse is, as Habermas (1995) states,

that the success-orientation of competitors is assimilated into a form of 
communication in which action oriented toward reaching understanding is continued by other means. In argumentation, proponents and opponents engage in a competition with arguments in order to convince one another (...) This dialectical role structure makes forms of disputation available for a cooperative search for truth (...) In discourse what is called the force of the better argument is wholly unforced. Here convictions change internally via a process of rationally motivated attitude change (Habermas 1995, 160).

2. Optimal moral tasks which challenge students moral judgment and discourse. Moral competencies are the abilities which we need to cope with moral tasks, i.e., moral problems or dilemmas. Coping with those tasks also helps to strengthen and differentiate our moral judgment and our moral discourse - but only if these tasks are not either to too easy or difficult. If the moral task is too difficult (e.g., if the problem is very salient for us) it may overwhelm or threaten us and thus prevent us from learning. The best teaching strategy thus is to confront students with hypothetical moral dilemmas, that is, serious dilemmas that are apt to stir up feelings of moral conflict but, at the same time, do not threaten us too much.

3. Alternating phases of challenge and support. The best way to keep students' affects in an optimal balance over the whole period of a class is to alternate phases of challenge and support through adequate instructions. This also ensures that attention rates and learning rates are high over the whole time span. Many participants are aware of the comforting climate created by these phase changes and tell us that they intend to use the KMDD as a model for starting their own discussions outside the class-room.

These three criteria are in no way new. Gustav Radbruch already argued in favor of a broad moral-democratic education. He remarks:

Of all the virtues, justice can least rely on intuition, feeling, and the naïve, unlearned consciousness (...) Justice needs abstraction of two kinds: it has to empathize with the situation of others and to generalize it. The generalization requires not only the sense of fairness, but also the capacity to make judgments. That capacity is difficult to develop without exercise (Radbruch 1993, 264).

Exercising moral judgement making begins on the deep, preconscious level when our internal orientations are activated if we "feel" a moral problem. However, many other mental (cognitive) processes follow, if we hear other people judging the same moral problem. Beyond this, in a free discursive exchange, we experience how diverse the moral views can be. Radbruch emphasized that the democratic way of life is only possible, if people learn what the meaning of pluralism and relativism is for democratic relationships. People behave in a democratic way when they resolutely present their own opinion but also do justice to the opinions of others, (so lehrt der Relativismus zugleich Entschiedenheit der eigenen und Gerechtigkeit gegen die fremde Stellungnahme), and when they are not persuaded by any higher point of view (Radbruch 2003, 4).

Radbruch remarks in many of his writings that the traditional "reforming of citizens" is not efficient as long as we only wish to change external behavior but not the inner orientation (Radbruch 1961, 51). He says, "this Pharisean term ,improvement' (das 
allzu pharisäische Wort 'Besserung') should be replaced in education by a more "mindoriented" term (innerlich gerichtet). In his project of democratic education we find not only the modules of such a teaching but also some instructions concerning the teacher's personality: a good teacher is not only a scientist, but also a very socially- and politically competent person ("the political orientation of today" is recommendable), who can clarify the practical problems of justice and law which are put daily by students (Radbruch 1993, 191).

Radbruch also made suggestions as to the method to be used for an "education toward justice" very similar to the criteria stated above. He presupposes an educational space for free discourse, in which students express "their unconscious intuitions" in the face of a real social conflict and try to understand, "how problematic law and justice can be" without any interference by a know-all authority.

Effective schools already operate to some degree in accordance with these three criteria (Lind 2002). However, schools could foster moral and democratic competencies even more effectively if they applied these criteria more fully. This is shown by Blatt and Kohlberg's method of dilemma discussion (Blatt \& Kohlberg 1975) and Lind's Konstanz Method of Dilemma Discussion (KMDD), which has been especially designed on the basis of the three criteria. The KMDD is used in schools, universities, prisons, military and many other institutions of education. It has proved to be highly effective when the teachers are properly trained (Lind 2016; Lerkiatbundit et al. 2006). Adequate teacher training is the key to successful moral and democratic education.

\section{Conclusion: \\ Schools Should Be the True Place of Moral-Democratic Education}

An autocratic government perceives education merely as a means to secure its political and economic power, and seeks to prevent the development of moral and democratic competencies; the sole emphasis is on rote learning and persistent testing of standardized knowledge. In contrast, a truly democratic government perceives education as a means of maintaining and promoting the common good and justice, and, hence, is determined to make the fostering of moral and democratic competencies the core topic of public schooling.

However, under circumstances of crisis, we assume that these self-sustaining mechanisms can collapse not only in autocratic states but in democratic states, too. In the case of Poland in the 1970's, the autocratic government faced an enormous economic and political crisis. Food shortage, workers' strikes and student protests prevailed. Many people were drawn into reflecting on the reasons for this crisis and into discussions with others. On the one hand, these reflections and discussions had a direct impact on the political system. The workers' union Solidarność was created and national andinternational politics responded to them. On the other hand, these cognitive processes also had an 
educational impact, as we had reported here. At least among the university students, for whom data is available, moral judgment competence showed a steep increase during this time. Yet, while similar increases were found in Germany not only during the 1970's but also in the 1980's, this development was abruptly stopped in Poland by the military coup d'etat. We assume that this not only changed the public climate but also had an impact on peoples' discourse behavior. The students who participated in the international FORMstudy were interviewed by Polish professors, whom they saw as representatives of the oppressing state. It seems that this setup of the study provides us with a very sensitive measurement of the degree of (mis-)trust between university students (and, by extension, probably also the Polish citizens in general) and their government.

However, we should note that moral development can come to a halt, and moral and democratic competencies can also regress, when less spectacular forms of crisis occur in a democratic system. This may happen as a consequence of neglect and ignorance when the public loses sight of the great importance of democratic education for the functioning of a democratic society. Such a "creeping" crisis in the democratic way of life seems to be happening in many countries today, as schools become more and more preoccupied with fulfilling governmental achievement standards and spend less and less time and expertise on moral and democratic education. The growing number of cases of corruption and deceit in the public and economic sphere should be taken as a warning sign. The main function of public education in schools and universities is, as Tocqueville (1960/1948) once concluded from his assessment of the young American democracy, to preserve and to foster the citizens' ability to uphold their rights and to care for one another. Thus he and other scholars agree that the schools must take up their special responsibility for maintaining and fostering the democratization process. For Thomas Jefferson (2008/1787), one of the leaders of the American Revolution, "the only sure reliance for the preservation of our liberty [is to] educate and inform the whole mass of the people." Last but not least, the great philosopher of law and law-maker Gustav Radbruch (1993, 263-267) emphathized the role of the school for developing a sense of rightness ("Rechtssinn") in the citizens of the democratic state: "School education alone is not capable of awakening the sense of rightness in anyone. This sense must manifest itself directly, by itself. The problem of justice reappears in the life of a school community almost every day. A teacher should only allow the students fully to experience what they live through every day, virtually every hour. He should only make them aware of their unconscious intuitions, and together with the students think through, from the beginning to the end, what they well know from their own intuitions, so that they have before their eyes a real, tangible example of how problematic law and justice can be."

The aim of democratic education is to enable citizens to resolve their conflicts through rational discourse and not through violence, force or brute political power. Democratic education does not mean that we ought to teach such a consensus. A consensus can only be achieved through public debates and political discourse, not through a school 
curriculum. Accordingly, Lind's (2016) method of dilemma discussion is designed to foster the ability to apply moral principles to decision-making and the ability to engage in a moral discourse on controversial issues, not to force students to reach a consensus. The best an educator can achieve is that in a heated debate each and every member is respected by the others, that is, nobody in class is physically attacked or humiliated or even personally criticized for his or her opinion on an issue. This aim of moral-democratic education has been aptly stated by Odo Marquard:

For this reason (...) this communication must be more than the kind of discourse (aiming at consensus) (...) It is precisely the oneness of discursive consensus which blots out manysideness, and the general then silences the particular... (Marquard 1994, 43).

\section{References}

Adam E. C. 1993. "Toward a Theory of Situation Awareness in Dynamic Systems." Human Factors 37(1)32-64.

Aristotle. 2009. Nikomachean Ethics. Tr. by W. D. Ross.

http://www.scribd.com/doc/4617088/Aristotle-Nikomachean-Ethics (accessed on 12.01.2009).

Bargel T., Markiewicz W., \& Peisert H. 1982. „University Graduates: Study Experience and Social Role - Empirical Findings of a Comparative Study in Five European Countries (FORM project)," in M. Niessen \& J. Peschar (Eds.), Comparative Research on Education. Oxford: Pergamon (55-78).

Birnbacher D. 2003. Analytische Einführung in die Ethik. Berlin - New York: Walter de Gruyter.

Blatt M. \& Kohlberg L. 1975. “The Effect of Classroom Moral Discussion upon Children's Level of Moral Judgment." Journal of Moral Education 4:129-61.

Brehm J.W. 1972. Responses to Loss of Freedom: A Theory of Psychological Reactance. Morristawn: General Learning Press.

Brehm J. W. \& Cohen A. R. 1962. Exploration in Cognitive Dissonance. New York: Wiley.

Darwin Ch. 1989. The Descent of Man, and Selection in Relation to Sex. The Works of Charles Darwin, ed. by P. H. Barrett \& R. B. Freeman. London: Pickering (Original 1871).

Dewey J. 1966. Democracy and Education. An Introduction to the Philosophy of Education. New York: The Free Press.

Dewey J. 1975. Moral Principles in Education. Cambridge: University of Southern Illinois Press. 
Gutmann A. 1999. Democratic Education (2 ${ }^{\text {nd }}$ edition). Princeton, NJ: Princton University Press.

Habermas J. 1986. Autonomy and Solidarity. Ed. by P. Dews. London - New York: Verso.

Habermas J. 1996. Between Facts and Norms. Trans. J. Rehg. Cambridge: Blackwell Publishers Ltd.

Habermas J. 1995. Moral Consciousness and Communicative Action. Trans. Ch. Lenhardt \& S. Weber Nicholsen. Introduction by T. McCarthy. Cambridge, MA: The MIT Press.

Harvey J. H. et al. 1974. "Perceived Choice as a Function of Internal - External Locus of Control." Journal of Personality 42:

Hemmerling K. 2014. Morality Behind Bars. Frankfurt am Main: Peter Lang. Herkner W. 2004. Sozialpsychologie. Bern - Göttingen - Toronto - Seattle: Huber. Jefferson T. 2008. Thomas Jefferson to James Madison, 1787. (Forrest version) ME 6:392 quoted in http://etext.lib.virginia.edu/jefferson/quotations/ (accessed on 20.12.2008).

Keasey C. B. 1974. "The Influence of Opinion-Agreement and Qualitative Supportive Reasoning in the Evaluation of Moral Judgments." Journal of Personality and Social Psychology 30:477-82.

Kohlberg L. 1964. "Development of Moral Character and Moral Ideology," in M. L. Hoffman \& L. W. Hoffman (Eds.), Review of Child Development Research, Vol. I. New York: Russel Sage Foundation (381-431).

Kohlberg L. 1970. "Education for Justice. A Modern Statement of the Platonic View," in N. F. Sizer \& T. R. Sizer (Eds.), Moral Education: Five Lectures. Cambridge, MA: Harvard University Press (57-83).

Kohlberg L. 1975. “Moral Education for a Society in Moral Transition.” Educational Leadership (October):46-54.

Kohlberg L. 1980. "High School Democracy and Education for a Just Society," in R. Mosher (Ed.), Moral Education. A First Generation of Research and Development. New York: Praeger (20-57).

Kohlberg L. 1984. The Psychology of Moral Development. Vol. 2: Essays on Moral Development. San Francisco: Harper \& Row.

Lewin K. \& Lippit R. A. 1938. "An Experimental Approach to the Study of Autocracy and Democracy. A Preliminary Note." Sociometry 1:292-300.

Lind G. 1978. „Wie misst man moralisches Urteil? Probleme und alternative Möglichkeiten der Messung eines komplexen Konstrukts" [How Does One Measure Moral Judgment? Problems and Alternative Possibilities of Measuring a Complex Construct]. In G. Portele (Ed.), Sozialisation und Moral. Weinheim: Beltz (171-201). Lind G. 1985. "Growth and Regression in Cognitive-Moral Development," in C. Harding (Ed.), Moral Dilemmas. Chicago: Precedent Publishing Inc. (99-114).

Lind G. 1986. "Cultural Differences in Moral Judgment Competence? A Study of West and East European University Students." Behavior Science Research 20:208-25. 
Lind G. 1987. "Moral Competence and Education in Democratic Society," In G. Zecha \& P. Weingartner (Eds.), Conscience: An Interdisciplinary Approach. Dordrecht: Reidel (37-43).

Lind G. 1989. "Measuring Moral Judgment: A Review of 'The Measurement of Moral Judgment' by Anne Colby and Lawrence Kohlberg." Human Development 32:38897.

Lind G. 2000a. "Moral Regression in Medical Students and Their Learning Environment." Revista Brasileira de Educacao Médica 24(3)24-33.

Lind G. 2000b. "The Importance of Role-Taking Opportunities for Self-Sustaining Moral Development." Journal of Research in Education 10(1)9-15.

Lind G. 2002. Ist Moral lehrbar? Ergebnisse der modernen moralpsychologischen Forschung. [Can morality be taught? Research findings from modern moral psychology]. Second Edition. Berlin: Logos-Verlag.

Lind G. 2008a. "The Meaning and Measurement of Moral Judgment Competence Revisited - A Dual-Aspect Model," in D. Fasko \& W. Willis (Eds.), Contemporary Philosophical and Psychological Perspectives on Moral Development and Education. Cresskill, NJ: Hampton Press (185-220).

Lind G. 2008b. "Teaching Students to Speak up and to Listen to Others: Cultivating Moral Democratic Competencies," in D. E. Lund \& P. R. Carr (Eds.), Doing Democracy and Social Justice in Education: Political Literacy for All Students. New York: Peter Lang Publishing (185-220).

Lind G. 2016. How to Teach Morality. Promoting Deliberation and Discussion, Reducing Violence and Deceit. Berlin: Logos-Verlag.

Marquard O. 1996. Skepsis und Zustimmung [Skepticism and agreement]. Stuttgart: Reclam.

Mischel W. \& Mischel H. 1996. “A Cognitive Social Learning Approach to Morality and Self-Regulation," in T. Licona (Ed.), Moral Development and Behavior. New York: Holt (84-107).

Nowak E., Schrader D., \& Zizek B. (Eds.), Educating Competencies for Democracy. Bern New York - Frankfurt am Main: Peter Lang Verlag.

Piaget J. 1976. "The Affective Unconscious and the Cognitive Unconscious," in B. Inhelder \& H. H. Chipman (Eds.), Piaget and His School. New York: Springer (63-71).

Radbruch G. 1961. Der Mensch im Recht. Göttingen: Vandenhoeck \& Ruprecht.

Radbruch G. 1993. Politische Schriften aus der Weimarer Zeit. Vol. II. Heidelberg: C. F. Müller.

Radbruch G. 2003. Rechtsphilosophie. Heidelberg: C. F. Müller.

Seligman M. E. P. 1975. Helplessness. San Francisco: Freeman.

Sprinthall N. A., Reiman A. J., \& Thies-Sprinthall L. 1993. „Role-taking and Reflection: Promoting the Conceptual and Moral Development of Teachers." Learning and Individual Differences 5(4):283-99. 
Tocqueville A. de 1960. Democracy in America. Vol. II (Original published 1848). New York, NY: Vintage Books. 
Ewa Nowak (Poznań), Georg Lind (Konstanz)

\title{
Mis-Educative Martial Law - The Fate of Free Discourse and the Moral Judgment Competence of Polish University Students from 1977 to 1983
}

\begin{abstract}
The reprinted paper refers to Georg Lind and his colleagues' MCT-based FORM study conducted at several European universities in 1977-1983, including Polish ones. After a short phase of democratization, in 1981 Polish society suddenly faced martial law. That experience had an impact on Polish students moral-, discursiveand democratic competences, as measured by MCT. When Ewa Nowak started her Alexander von Humboldt Foundation supported research stay under the supervision of Professor Georg Lind (University of Konstanz, 2008-2010), they were inspired to revisit and discuss the puzzling Polish research findings of 1981/3. According to their main hypothesis, martial law restricted free speech at universities, and free speech is a key facilitator of the development of moral and democratic competence. In 2018, after a decade of collaborative research on moral and democratic competence, Lind, Nowak and colleagues started a new international MCT study in several Central- and East European countries to examine the impact of the contemporary constitutional crisis in Poland (and the institutional crisis within the European Union) on students' moral and democratic competencies. In 2018/9 the 40th anniversary of the Moral Competence Test (MCT) and Konstanz Method of Dilemma Discussion (KMDD) will be celebrated. We would like to provide you with the most recent research findings soon.
\end{abstract}

Keywords: moral competence; democratic comtetence; Polish students; MCT; martial law in Poland 1981; the lack of democratic liberties; the regression of moral and democratic competenties in students

Ethics in Progress (ISSN 2084-9257). Vol. 9 (2018). No. 2, Art. \#5, pp. 56-74.

Creative Commons BY-SA 3.0

Doi:10.14746/eip.2018.2.5 